\title{
Discussion on Ideological and Political Education in Pathology Education in Medical Colleges
}

\author{
Ningbo Huang \\ Ningxia Medical University, Yinchuan 750001, Ningxia, China.
}

Abstract: With the advent of the new era, teachers in colleges and universities have actively combined the teaching content with ideological and political education under the guidance of the ideological and political philosophy of the course. I hope that students can ensure professional literacy through the participation of classroom learning activities. Under the rapid promotion of patriotic spirit, dialectical spirit, humanistic spirit, rule of law spirit and scientific spirit, it can grow into a new type of talent that meets the requirements of social and political development. This article starts from different perspectives and introduces specific methods of ideological and political education when teaching medical pathology teachers in medical colleges, hoping to provide references for other medical educators.

Keywords: Ideological and Political Education; Medical Education; Colleges and Universities; Pathology Classroom

The ideological and political concept of the course requires teachers to ensure the smooth progress of the teaching content of professional subjects when conducting teaching activities, but also needs to introduce ideological and political education into the overall teaching activities, which plays a role in the ideological and moral level, personality improvement and political literacy of students. Active promotion effect. Pathology education, as one of the compulsory courses for medical students, not only requires students to have critical thinking skills and professional qualities, but also requires students to have high professional ethics and ideological politics under the guidance of correct values. Accomplishment, and then become high-quality talents that meet the standards required by the social medical industry. So how to enable students to get better development under the guidance of ideological and political concepts during the pathological teaching activities is the main research content of this article.

\section{Attach importance to patriotic education}

As an important content of ideological and political education, patriotism is not only a driving force for national rejuvenation, but also a spiritual pillar that stimulates students' patriotism and promotes their better development. Therefore, when teachers carry out pathology classroom teaching activities, they need to pay attention to the education of patriotism to students, so as to help students establish correct ideological and political concepts, and enable students to obtain more comprehensive development. Pathology courses cover a wide range of content, and have high requirements for students' learning ability, speculative awareness and inquiry ability. Therefore, teachers can according to the specific teaching content, so that students can develop from the continuous changes in the country, and feel the connection of better control of the disease, so that the learning efficiency can be rapidly increased in the process of inspiring students' patriotism.

\section{Attach importance to scientific spirit education}

The scientific spirit means that when teachers carry out teaching activities, they can guide students to continue in-depth

Copyright $(2020$ Ningbo Huang

doi: 10.18686/ahe.v4i10.2893

This is an open-access article distributed under the terms of the Creative Commons Attribution Non-Commercial License (http://creativecommons. org/licenses/by-nc/4.0/), which permits unrestricted non-commercial use, distribution, and reproduction in any medium, provided the original work is properly cited. 
exploration of objective laws, and in continuous exploration and practice, they can always get better development under the guidance of truth. Therefore, when teachers introduce ideological and political education in the pathology classroom, they also need to educate the students' scientific spirit, so that they can use facts as the basis for learning and use scientific thinking skills to complete the knowledge content in the process of participating in the classroom knowledge learning. Draw. Many existing pathological theories are the results of decades of rigorous pathologists' field investigations and careful research. Therefore, students should always carry out meticulously under this concept of truth-seeking, pragmatic and active inquiry. Learning of professional knowledge. Therefore, teachers should get rid of the teaching method of unilaterally explaining knowledge to students, and through the analysis of college students' interest in learning and speculative ability, improve the content of the teaching in a targeted manner, so that students can abandon the bad habits of relying on teachers to learn knowledge, autonomous Inquiry into classroom knowledge, and through the use of inquiry consciousness, can continue to study and think about pathology knowledge. In this pathology class that values scientific spiritual education, not only can students' learning ability be rapidly improved, but also in the process of training their thinking consciousness and spiritual quality, they can help students get better under the guidance of ideological and political education concepts. development of.

\section{Attach importance to humanistic spirit education}

As an important base for cultivating high-quality medical talents in China, medical colleges not only need to teach students more professional medical theoretical knowledge, but also need students to have a higher professional quality and practical ability, and can always be in the humane spirit of benevolence and benevolence. In it, he became a white angel who saved lives. Although medicine can help people cure diseases, it is not a panacea. Even for some medical diseases that have not been overcome so far, many students cannot stop the pace of death. Therefore, students not only need to have professional medical knowledge, but also should have good interactive communication with patients so that patients can face diseases with an objective attitude under the leadership of positive emotions. Therefore, when conducting pathological classroom teaching activities, teachers also need to strengthen the education of humanistic spirit, so that students can realize the relationship between doctors and patients, should not rely on medical technology, and should also be in close communication and interaction between the two parties., So that patients can better enhance the self-confidence of curing diseases under the humane care of doctors. Through the introduction of humanistic spirit education, not only can the professional spirit of students be improved, but also a sense of professional responsibility can be stimulated, so that students can become white angels who save the lives of patients in continuous efforts.

\section{Conclusion}

Through the transformation of teaching perspectives, teachers' introduction of curriculum ideological and political concepts in conjunction with the development of the times when conducting pathological classroom teaching activities is not only an effective integration of teaching and education perspectives, but also an inevitable requirement for the implementation of General Secretary Xi's ideas in the new era. This will not only enable students to establish corresponding political literacy and ideological values through the study of classroom knowledge, but also enable students to establish a stronger professional ethical awareness and noble medical ethics in the process of mastering professional skills, and then grow into Highly-qualified talents who can shoulder the better future development of China's medical industry.

\section{References}

1. Du QH, Wang Q, Zhang YZ, et al. Exploration and practice of “curriculum thinking” in the teaching of pathology in traditional Chinese medicine school. Education Modernization 2020; 7(35): 172-174.

2. Chi XS, Shao CY, Fan XY, et al. The significance of integrating medical humanistic education into ideological and political education for the cultivation of medical students_-Based on the perspective of college counselors. Health Vocational Education 2020; 38(08): 28-29.

3. Gu RG, Liu YY. Construction and practice of curriculum ideology and politics system in higher vocational medical colleges based on the construction of resource database- Taking Heze Medical College as an example. Vocational and Technical Education 2020; 41(11): 71-75. 